\title{
ダイナミックレーザ干渉画像法による液滴蒸発過程の多次元計測*
} \author{
Multidimensional Measurement of Evaporating Droplets
by Dynamic Interferometric Laser Imaging for Droplet Sizing \\ Tatsuya KAWAGUCHI, Takushi SAITO and Isao SATOH ${ }^{* 2}$ \\ ${ }^{* 2}$ Graduate school of mechanical and control engineering, Tokyo institute of technology \\ Ookayama 2-12-1 Meguro-ku, Tokyo, 152-8552, Japan
}

川口 達也 ${ }^{* 1}$, 齊藤 卓志 ${ }^{* 1}$, 佐藤 勲 $^{* 2}$

\begin{abstract}
The paper describes the further improvement of interferometric laser imaging for droplet sizing technique that is the novel Lagrangian approach for the measurement of droplet size and velocity vector by means of a high-speed and high-resolution camera in conjunction with the double-pulsed high-frequency Nd:YLF laser. Measurement uncertainties due to the geometric optical approximation as well as the refractive index modulation were numerically analyzed. The technique was applied to the measurement of the evaporating ethanol spray. The size transition of the single droplet within a few milliseconds was experimentally investigated. The results led us to evaluate the mass transfer rate at the gas-liquid interface of the individual droplet.
\end{abstract}

Key Words : Particle Sizing, Velocimetry, Spray, Evaporation, Mass Transfer, Laser, Interferometry, Image Processing

1. 緒言

液体燃料の蒸発・凝縮に関連する気液界面での熱物質移動現象を論ずる際に兴の論拠となす処は，マクロ的な 時空間スケールの大きい統計的な測定結果をもとにアナロジーから構築したモデルであり，実験および数值計算 などに利用されてきた . 従来よりも更に微視的メカニズムへの考慮に立ち戻って議論を展開するには，分散相の

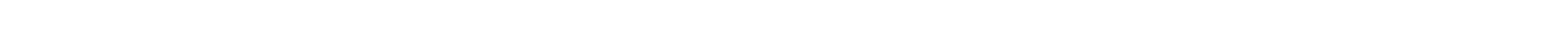
空間分解能にて計測し，諸因子間の相関関係を直接的に調べる手法を確立することが必要となる．

流体中を運動する球形液滴の挙動および粒径測定に関しては, カメラによる直接拡大撮影や，レーザドップラ流 速測定法 (laser Doppler velocimetry, LDV) 光学系による散乱光強度を利用した計測法が用いられてきた . 光の後, 位 相法 LDV(phase Doppler anemometry , PDA) の開発 ${ }^{(1)} に よ り$ 粒径の測定精度が格段に進歩し，信号処理法の改良 ${ }^{(2)}$ ， 質量流束測定 ${ }^{(3)}$ などに応用されてきた . 位相法 LDV はレーザビームを交差させた点を通過する粒子について粒径 と速度を高空間分解能にて計測することができるが, 点計測法であるため粒子間の空間的な相互関係の把握や間欠 噴霧などの非定常的な流れ場の解析に対して多くの困難が伴った ・レーザ干渉画像法 (Interferometric Laser Imaging for Droplet Sizing, ILIDS) は球形粒子にレーザ光を照射したときの散乱光強度の空間分布から粒径を求める手法であ り, Hesselbecher ら ${ }^{(4)}$ は幾何光学近似 (geometric optical approximation, g.o.) により粒径と干渉縞の間隔との関係式 を導くとともに，標準液滴発生装置を用いて式の妥当性を確認した . 干渉画像法を実流動場に応用した研究例 ${ }^{(5)(6)}$ においては，いずれも粒径の高精度測定が可能であり，干渉画像法が空間の粒径分布測定に有効であると結論づ けている．さらに撮影光学系を大幅に改良した干渉画像法により，高濃度の実噴霧場への適用 ${ }^{(7) ~(9)}$ が行われ，従 来，位相法 LDVにより測定可能であつた空間のある一点の粒径および速度の確率密度のみならず，瞬時・面的な 粒径確率密度分布や, 液滴径別にアンサンブル平均処理を行った速度ベクトルの呈示など, 新しい計測パラダイ ムが展開されてきた .

\footnotetext{
${ }^{*}$ 原稿受付 2011 年 5 月 29 日

${ }^{* 1}$ 正員, 東京工業大学大学院理工学研究科機械制御システム専攻 （干152-8552 東京都目黒区大岡山 2-12-1）

${ }^{* 2}$ 正員, フェロー, 東京工業大学大学院理工学研究科機械制御システム専攻

E-mail:kawat@mep.titech.ac.jp 
しかしながら噴霧の工業応用用途においては蒸発や凝縮，あるいは燃焼を伴う反応場を取り扱う系が非常に多 くみられ，前述の改良された干渉画像法を含め，これまでの統計的な分散粒子評価では，兴のミクロ的なメカニ ズムの解析と，熱物質移動モデル構築に必要な実験的検証データの提供という観点において限界があった . 単一 液滴の蒸発に関する研究 ${ }^{(10)(11)}$ は古くからおこなわれており, 球形粒子に対する熱物質移動の簡易モデルが提案さ れてきたが, 液滴群の挙動を空間的かつ時系列に捉えうるさらに精緻な測定手法が必要となる . 個々の粒子をラ グランジ的に追跡することにより, 径の変化や粒子の飛翔挙動を実験的に解析することが出来, 更にレーザ誘起 蛍光法等の連続相のスカラー量測定法との複合計測 ${ }^{(12)}$ により, 連続相・分散相双方からの移動現象の理解が可能 となる. 乥こで本研究では, 近年利用可能となってきた高速度・高解像度カメラと, 高出力・高繰返しパルスレー ザを用い, $\mathrm{kHz}$ オーダーでの粒径・速度分布計測を行い，蒸発・凝縮過程にある液滴群挙動の動力学的な解析を 実現するダイナミックレーザ干渉画像法 (Dynamic ILIDS) を開発した . 液滴の蒸発過程を時々刻々と正確に捉える ためには, 単に高速度撮影システムを導入すれば足りるという事ではなく，高速度撮影に必要な送受光系双方の 計測パラメータの最適化について検討する必要がある. また，幾何光学近似法により導出された粒径算出式 ${ }^{(4)}$ の妥 当性についても，生成する干渉縞のパターンが粒径変化により受ける影響について, Mie 散乱理論を用いて詳細に 検討した . 実験では高温雾囲気中に噴射されたエタノール液滴を対象として，ミリ秒以下のサンプリング周期で 時々刻々と変化する個々の液滴径のラグランジ計測を行い, 物質移動流束や蒸発速度定数などを算出した .

記 号 表

\begin{tabular}{cll|lll}
\hline$A$ & 表面積 & $\mathrm{m}^{2}$ & $\alpha$ & 集光角 & $\mathrm{rad}$ \\
$D$ & 拡散係数 & $\mathrm{m}^{2} / \mathrm{s}$ & $\phi$ & ノズル内径 & $\mathrm{m}$ \\
$H$ & 干渉像高さ & - & $\lambda$ & 波長 & $\mathrm{m}$ \\
$K$ & 蒸発速度定数 & $\mathrm{m}^{2} / \mathrm{s}$ & $\mu$ & 粘性係数 & $\mathrm{Pa} \cdot \mathrm{s}$ \\
$L$ & 干渉像幅 & - & $v$ & 動粘性係数 & $\mathrm{m}{ }^{2} / \mathrm{s}$ \\
$N$ & 干渉縞数 & - & $\theta$ & 散乱角 & $\mathrm{rad}$ \\
$N_{A}$ & 物質移動流束 & $\mathrm{kg} / \mathrm{m}^{2} \cdot \mathrm{s}$ & $\rho$ & 密度 & $\mathrm{kg} / \mathrm{m}^{3}$ \\
$M$ & 分子量 & - & $\tau$ & 緩和時間 & $\mathrm{s}$ \\
$R e_{p}$ & 粒子レイノルズ数 & - & $\tau_{d}$ & 蒸発時間 & $\mathrm{s}$ \\
$S c$ & シュミット数 & - & $\omega$ & 質量分率 & - \\
$S h$ & シャーウッド数 & - & & & \\
$T$ & 温度 & $\mathrm{K}$ & 添字 & & \\
$V$ & 体積 & $\mathrm{m}$ & & \\
$c$ & 比熱 & $\mathrm{J} / \mathrm{kg} \cdot \mathrm{K}$ & $c$ & 空気 & \\
$d$ & 直径 & $\mathrm{m}$ & $d$ & 分続相相 & \\
$k$ & 熱伝導率 & $\mathrm{W} / \mathrm{m} \cdot \mathrm{K}$ & $e$ & エタノール \\
$m$ & 屈折率 & - & $s$ & 表面 & \\
$p$ & 圧力 & $\mathrm{Pa}$ & $v$ & 速度 \\
$r$ & 半径 & $\mathrm{m}$ & $T$ & 温度 \\
$u$ & 速度 & $\mathrm{m} / \mathrm{s}$ & $\infty$ & 無限遠 & \\
\hline & & & & \\
\hline
\end{tabular}

2. 測定原理と装置

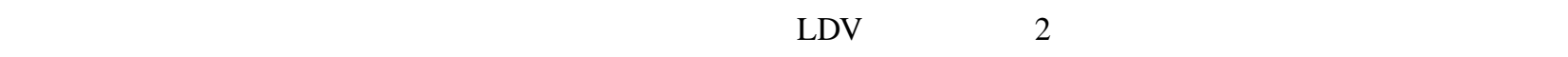
ら発生するドップラバースト信号の時間的な位相差を算出する手法であるのに対し，レーザ干涉画像法は, 透明球 形粒子からの反射光と屈折光の位相差により空間に生成される干渉縞を瞬時に観測する手法である . 位相法 LDV では，角度をもって入射する二本の光束によって得る屈折光同士または反射光同士の干渉を用いているのに対し， 干渉画像法では一本の入射光による反射・屈折光の干渉を用いる点に特徵がある . 従って干渉画像法ではパルス レーザの利用が可能であり, 時間軸方向のドップラ信号の位相差から径を求める位相法 LDV に比べて , 原理的に 
高い時間分解能にて計測が可能である . 具体的には，Q スイッチ付きパルスレーザの発振時間である $5 \mathrm{~ns} て ゙$ 粒径 の決定を行うことが可能である . また , 二本のビームおよび複数の受光光学系の焦点位置を空間の一つの点に合 致させることは, 調整に多大な労力を要するが , 干渉画像法では一枚のレーザシート内にある粒子の散乱光を画 像により得るため, 光学装置の調整が非常に容易である利点がある .

干渉画像法においては, 液滴径 $d$ を次式により求める ${ }^{(4)}$.

$$
d=\frac{2 \lambda N}{\alpha}\left(\cos (\theta / 2)+\frac{m \sin (\theta / 2)}{\sqrt{m^{2}-2 m \cos (\theta / 2)+1}}\right)^{-1}
$$

$\lambda$ はレーザ波長， $\alpha, \theta$ は光れ光れ集光角よび散乱角であり， $m$ は周囲媒体に対する液滴の相対屈折率の実部で ある.波長, 角度などは撮影装置により決定されるパラメータであるから, 液滴径 $d$ は上記光学定数を比例係数 として, 液体の相対屈折率 $m$ と干渉像中の縞の数 $N$ の計数のみから求めることができる. Mie 散乱領域において は, 散乱光強度の絶対值はおおよ光 $d^{2}$ に比例し，また照射光強度の変動の影響を直接的に受けるが，本手法にお ける干渉縞の本数は散乱光強度に依存しないため, 較正の必要が無く粒径の絶対測定が可能である.上式により 測定可能な液滴の下限に関して，一般的に粒径パラメータ $\pi d / \lambda$ が 20 以上であれば幾何光学近似の適用が可能で あるとされる ${ }^{(13)}$. 例えば波長 $527 \mathrm{~nm}$ の光源を用いる場合 , 測定可能な粒径の下限は約 $2 \mu \mathrm{m}$ となる .さらに小径 の粒子を計測する場合は，より短波長の光源を用いることで，波長に対する相対的な粒子径，即ち粒径パラメー タを大きくすることが可能となる . 短波長光源は振動数が高く, 一般的にディジタルカメラの感度も赤外光源に比 ベて高いため, パルス発振の Nd:YAG, Nd:YLF 等の高出カレーザの第 3 ・第 4 次高調波を可干渉光源として使用 することが考えられるが, 一方で水, 燃料などの液体は可視域において透明, 即ち吸収係数がほとんどゼ口であ るものの，紫外域において非常に強い吸収を有するため，単純な短波長化を以って粒径パラメータの増加，即ち 小径粒子計測への拡張を行うことは容易ではない．したがって，式 (1) 中の波長 $\lambda$ の短波長化による測定可能粒 径レンジの下方拡張は $\lambda=400 \mathrm{~nm}$ 程度が下限と考えられる。

前述の幾何光学近似による確立された粒径計算法に対して，干渉画像法では高解像度カメラにより個々の液滴 によるレーザ散乱光を非焦点面にて取得，蓄積した干渉画像列に対して画像内スキャニングを行い，粒子の位置， 径, 速度を自動的に算出する手法が開発された ${ }^{(7)}$. 特に干渉縞の光学的圧縮による空間分解能の向上および画像

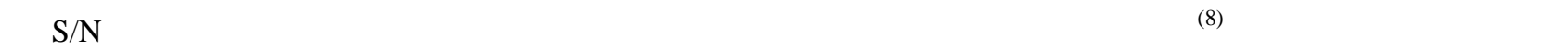
およびレーザドップラ流速測定法を用いて統計量の比較により評価しているが, 乥れ以外の幾何光学近似自体に 起因する不確かさや, 粒径算出係数の変動要因についての詳細な検討については充分とは言い難い. 更に, 時々 刻々と変化する液滴の蒸発過程をラグランジ的に解析する際には, 従来, 評価の中心としていた各種平均径, 分 散，モーメントに関する統計量の算出の際には顕在化しなかった誤差発生か懸念されるため, 粒径算出精度に関 してさらなる検討が必要であると考えられる．

粒径算出式 (1)の各変数を詳細に検討すると, 散乱角 $\theta$, 集光角 $\alpha$, 波長 $\lambda$ は装置に関する值であり, 測定中は 定数とみなすか，または少なくとも流動状況に影響されるパラメータではないと考えられる．他方，屈折率 $m$ と 干渉縞本数 $N$ につては, 粒径算出精度に与える影響を充分に検討する必要がある.さらに, 式 (1) は幾何光学 近似法による簡易モデルであるため, 近似兴のものに起因する不確かさを検討する必要がある . 次項以降におい ては, (i) 三次元性の高い流れの時系列計測を行うために増加させるレーザシート厚さが , 干渉像サイズに与える 影響, (ii) 液滴径算出式の前提となる幾何光学近似の近似精度, および (iii) 温度変化による屈折率变化の影響, に ついて詳細な検討を行った。

図 1 に計測装置の概略図を示す. 光源としてダブルパルス発振が可能な高繰返し Nd:YLFレーザ DM10-527 型

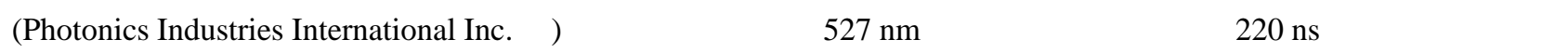
数および発振周期を $4000 \mathrm{~Hz}, 0.25 \mathrm{~ms}$ とした . 照射する光の偏波面を調整するため， $\lambda / 4$ 波長板および $\lambda / 2$ 波長

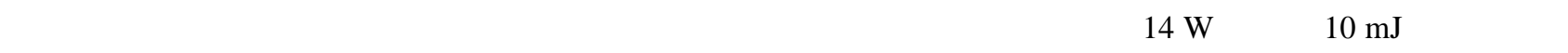
た , シート光学系を作成するためにシリンドリカルレンズ群を用いた .レーザシート厚を変化させ , 得られる画 像の比較を行った . 画像撮影には IDT 社製 MotionXtra N4 型高速度 CMOS カメラを用いた . 散乱角および集光角

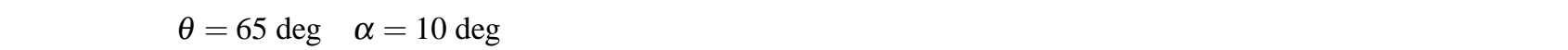




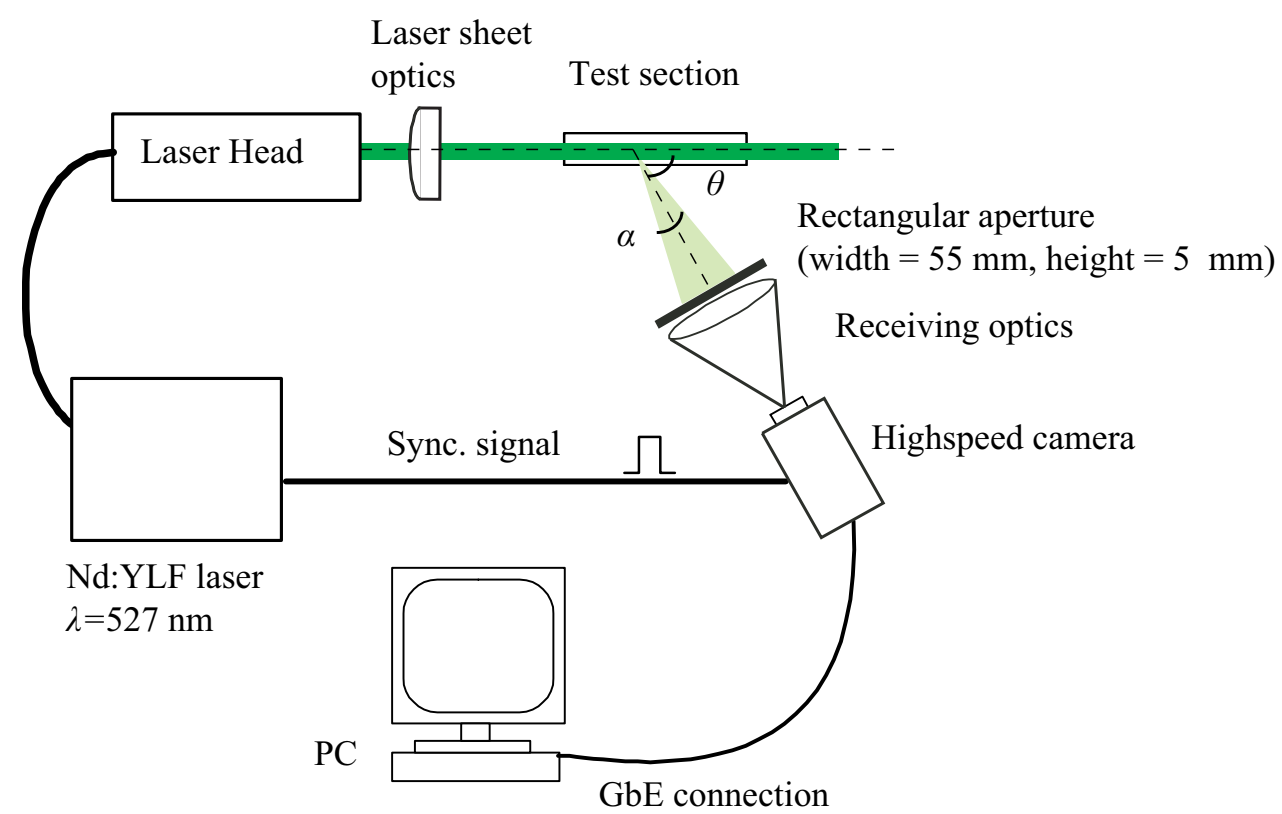

Fig. 1 Experimental set-up of the interferometric laser imaging system. The measurement system consisted of a high-speed camera, defocusing optics with a rectangular aperture, Nd:YLF laser with a laser sheet optics and personal computer for the image processing. Both camera and laser equipment were synchronized by the electric signal.

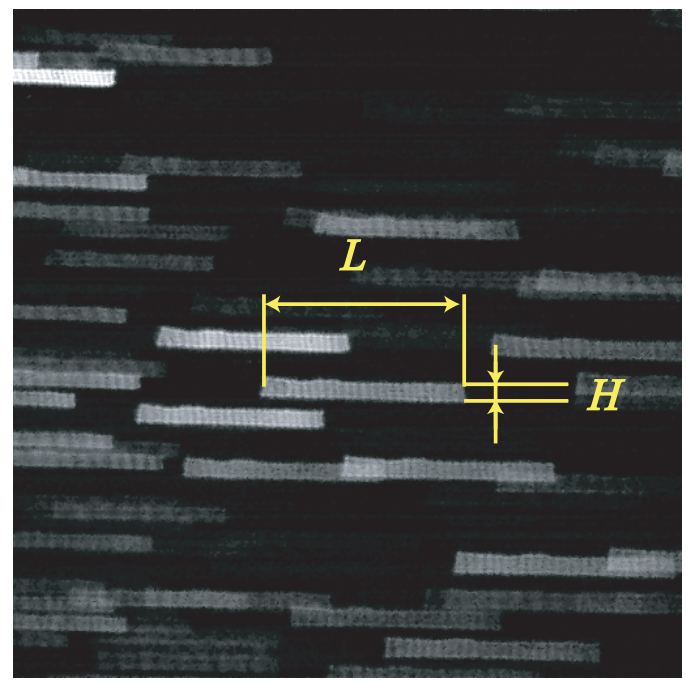

Fig. 2 An example of the captured image. Each rectangular interferogram corresponds to a droplet, the frequency of the fringe is proportional to the diameter of droplet. The rectangular shape of the interferogram is due to the shape of the aperture in front of the receiving lens in Figure 1. Physical dimension of the image is $14 \mathrm{~mm} \times 14 \mathrm{~mm}$.

光光学系の焦点位置は撮像素子面よりも後方位置にある設定とした . 非焦点撮影時においては，輝点の像は光の 点広がり関数を反映する形状となり, 通常はレンズの開口形状を反映した円形形状となるが, 本研究では噴霧中 の複数液滴像の重なりの影響を軽減するために，矩形アパーチャを受光レンズ先端部に設置した . 矩形アパーチャ のサイズは幅 $55 \mathrm{~mm}$, 高さ $5 \mathrm{~mm}$ とした . アパーチャの幅は集光角に直接影響するため, 粒径測定レンジの下限 拡大を目的としてレンズの有効開口とほぼ同一の值となるよう設定した . アパーチャの高さについては, 干渉像 同士の重なり軽減のためにアパーチャ端部による回折の影響が顕在化しない程度に小さくすることか望ましいが， 一方で画像処理による個々の液滴の速度算出の測定精度向上のために, 干渉像の高さが取得された画像上におい 
て数ピクセル以上となる必要があることから, 両者のバランスを考慮して決定した . 一度に計測可能な測定体積の

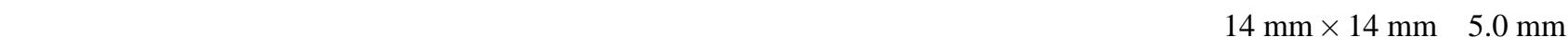
と設定した .

図 2 に , 本計測装置により得られる瞬時の画像の一例を示す . 画像中の干渉像の形状は前述の矩形アパーチャの

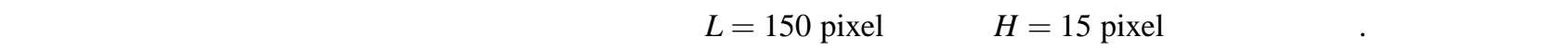
データの取得および蓄積は, カメラの内蔵メモリに行われ，一定枚数の画像露光終了後にギガビットイーサケー ブル経由で PC に転送した . 解像度は最高で $1016 \times 1016$ ピクセルであり，一画素あたり 10 bit の分解能を有す る . フルフレームでの最高撮影速度は $3000 \mathrm{~Hz} て ゙ あ り ， 512 \times 512$ ピクセルに設定すると $4000 \mathrm{~Hz}$ での撮影が可能 である . 画像撮影系の電子シャッターの開放と，レーザ装置のパルス発振タイミングは, 同期信号により連動さ せた . カメラ内蔵メモリの容量は $1.3 \mathrm{~GB} て ゙ あ り ，$ 画素数と撮影速度から決まる連続撮影可能時間は，本実験条件 において最大で 1 秒間である . 得られた画像を独自に開発した画像処理ソフトウエアにより処理し，個々の粒子 の位置，粒径，速度ベクトルデータを抽出した . 本計測に必要な装置およひ設定は基本的に粒子画像流速測定法 (particle image velocimetry, PIV) と同樣であるが，異なる点は散乱角，非焦点撮影および処理ソフトウエアである 噴霧液滴の多次元計測は Maeda ら ${ }^{(7)}$ により完成されているが, 計測の時間分解能は Q スイッチ付きダブルパルス $\mathrm{Nd}$ :YAG レーザの発振周期である $67 \mathrm{~ms}$ であった . 乥れに対し，本研究で新たに構筑した計測システムでは，干 渉画像を $0.25 \mathrm{~ms}$ 間隔で連続的に撮影することが可能となり，著しい時間分解能の向上を果たした．また，本手法 では少なくとも画像数フレームに同一液滴の干渉像が連続して撮影されるため，径の時間変化の測定のみならず， 面外移動による粒子像消滅の検出が容易となり，多時刻間の粒子の対応付けがより正確となる利点がある．

\section{$2 \cdot 1$ レーザシート厚さに関する考察}

干渉画像法では PIV 法と同樣, 非常に薄いレーザシートにより検査体積を照射し，微小粒子からの散乱光をディ ジタルカメラにより撮像する．PIV 法においては輝度情報のみを用いるため，粒子の散乱光が得られれば良く，パ ルス発振の Xe 光源や, 高出力の LED 光源も利用可能であるが, トレーサ追従性の観点から径の小さな粒子を用 いると散乱光強度が著しく弱くなるため, 特に高速気流測定においては空間のごく狭い領域に光エネルギを集中 させる目的からレーザが用いられる，一方，本手法では液滴による反射光と屈折光の干渉から直径を計測するた め，可干渉光源の使用が必須であり，同樣の理由からシリンドリカルレンズを用いた薄いレーザシートを用いる のが一般的である . 流れ場が二次元である場合, または面外れ方向の速度成分が他の面内速度成分に比べて著し く小さい場合は，照射するレーザシート面を流れと平行にすることにより，移動する分散粒子を時々刻々とレーザ シート内に捉え追跡撮影することが容易であるが, 噴霧では運動量の大きい分散相粒子と気相の乱れが相互に複 杂隹に干渉し乱流状態となるため，速度分布に二次元性を仮定することは一般的にできない，従来型の干渉画像法 では, 粒子による強い散乱光を得るため, また計測の空間分解能を向上させるために，レーザシートの厚さを可 能な限り薄くすることか望ましいとされていたが, 一方で粒子による表面反射光と内部屈折光の干渉を必要とす るため，測定対象となる粒子の直径よりもレーザシートを薄くすることは原理的にできない，従って，典型的な レーザシート厚さは液滴を計測する場合において $100 \mu \mathrm{m} \sim 500 \mu \mathrm{m}$, 気泡計測の場合においては $1 \mathrm{~mm}$ 程度に設定 されていた ${ }^{(8)}$.

ダブルパルスレーザを用いた従来手法においては, 速度決定のために最低 2 時刻の粒子同士の対応付けがあれ ば充分としており, 兴の時間間隔は粒子の移動速度と撮影倍率に応じて $1 \mu \mathrm{s}$ から数十 $\mu \mathrm{s}$ と設定されるため, 粒 子のレーザシート面外への移動による対応付けの棄却頻度は数\%以下であった . また，従来法の画像処理におい ては，この時間間隔内に粒径が変化しないことを前提として相互相関法により個々の粒子の速度べクトルを算出 していた . 例えば，面外方向の速度成分を $10 \mathrm{~m} / \mathrm{s}$ とし，ダブルパルスレーザ発振間隔を $5 \mu \mathrm{s}$ とすると，移動量は $50 \mu \mathrm{m}$ となる . この值は上記の典型的なレーザシート厚さに比べて充分に小さいため, ダブルパルス撮影の 2 時 刻間に，シート内に粒子を捕捉することができる．

しかし本研究で測定対象とする液滴の蒸発・凝縮過程のラグランジ的な追跡においては, 粒径の变化が検出可 能な程度の一定時間内に, 同一の液滴による干渉像が連続する数フレーム内に捉えられている必要があり, 蒸発 速度に応じて少なくとも数十 $\mu \mathrm{s}$ から数 $\mathrm{ms}$ 間の液滴挙動を連続的に捉える必要がある. 即ち，一般的な噴霧を計 測対象とする場合は, レーザシート厚さを増加させ , 面外移動による干渉像の消失を低減させる必要がある.当 
然 , レーザシート内の光エネルギ密度が低下するため, より高出カのレーザ光源が必要となる .
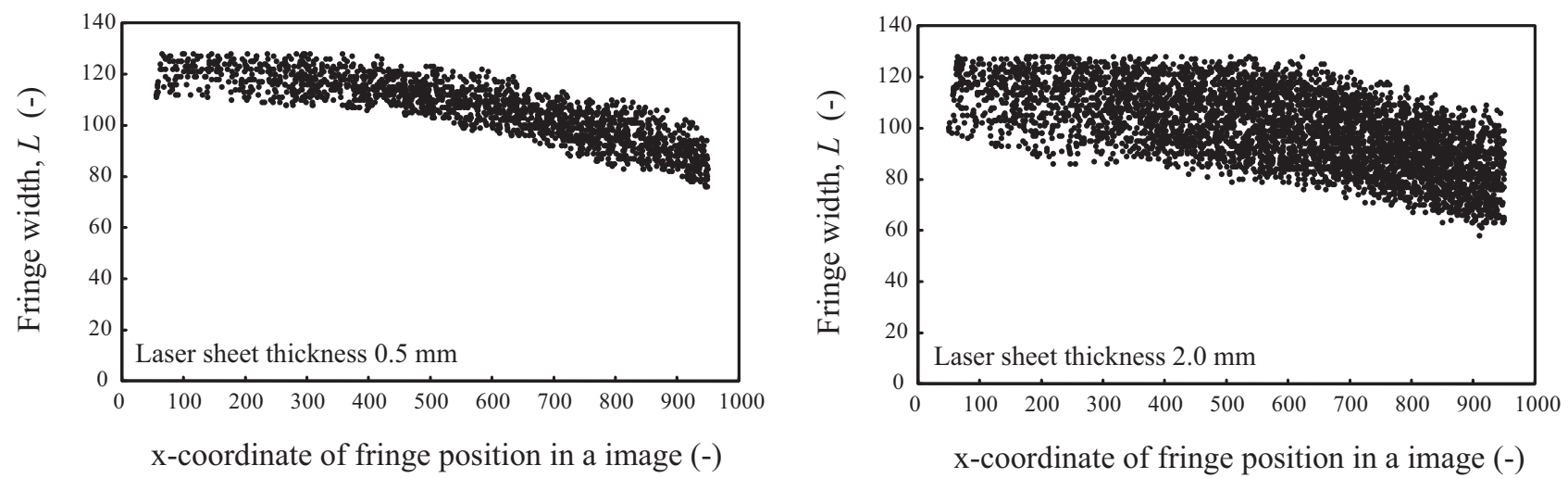

Fig. 3 Measured fringe image length as a function of the $x$ coordinate in the image, and the dependency on the laser sheet thickness. Thick laser sheet disperses the fringe image length. As increase the $x$ coordinate, mean value of fringe width is decreased due to the off-axis alignment of the receiving optics.

実際の計測においては, 粒径算出式 (1)のうち干渉縞本数 $N$ を画像処理により算出するが, 本手法においては フーリエ変換によるスペクトル算定を用いており, 離散フーリエ変換により得られる周波数と, 空関数サイズ, 即 ち空関数のサンプリング点数の双方が必要となる . これは非焦点の度合いが一定以上 (far field arrangement) であ れば, 干渉縞本数は非焦点の度合いに影響されず粒径のみの関数となり ${ }^{(14)}$, 非焦点の度合いを増加させると撮影 画像中の干渉縞が相似的に拡大され，結果として空間周波数が減少するためである . 図 3 は, ソリッドコーンノ ズルによる噴霧液滴を本手法により実際に撮影し, 得られた干渉画像をソフトウエアにより処理し, 検出された 個々の干渉像の幅を画像中の横方向位置の関数として表したものである . 縦軸は検出された干渉像の幅を画像の ピクセル単位で表したものであり，横軸は画像中の干渉像位置を同じくピクセル值を用いて表している . 個々のプ ロットが一個の液滴に対応し，ここでは例としてレーザシート厚さ $0.5 \mathrm{~mm}$ および $2.0 \mathrm{~mm}$ を示した .レーザシー 卜厚さの増加によりプロットが上下に広く分布するようになり，干渉像の幅の分散か増加していることが分かる． また，全体的な傾向として右下がりとなっているが，これはレーザ光軸と受光光学系がにらみ角を有しているため である . 即ち，画像中の右側に対応する位置においてはレーザシート位置がより受光系の焦点面に近く，逆に画 像左側の領域においてはより焦点面に遠いためである .千渉像の幅は焦点外れの度合いの関数であり，本計測装 置の光学配置においては, カメラ設置側を基準としてレーザシートの奥側に撮影光学系全体の焦点位置が存在す る.従って，レーザシート中心軸より奥側に存在する粒子は合焦点状態に近く干渉像の幅が小さくなり，逆にレー ザシート中心より手前側の粒子はより焦点外れ位置に存在することになるため干渉像の幅が大きくなる .この関 係は, 受光光学系全体の焦点面がレーザシートより手前にあるような光学配置では逆となることに注意を要する . レーザシート厚さが 0 の極限においては, 粒子の奥行き位置のばらつきは無くなり, 粒子像の幅は位置による単 一の值となるため, 従来の干渉画像法では干渉像幅を位置のみの関数としていたが, 本研究においては個々の液 滴による干渉像を時々刻々の画像内に捉える目的からレーザシート厚さを相対的に厚くしているため，画像中の 同位置においても干渉像の幅を一定値と仮定することはできず，画像処理により個々の粒子ごとに像サイズ $L お$ よび $H$ を決定する処理を追加した .

図 4 は, 図 3 に示した測定結果と同樣の実験を,レーザシート厚さ $0.5 \mathrm{~mm}$ から $5 \mathrm{~mm}$ まで変化させて行い, 得 られた干渉像幅の標準偏差を平均值で除した相対的な值として表示したものである．この実験では撮影レンズの 焦点距離を $85 \mathrm{~mm}$ とし, 撮影光学系の倍率は 1.0 倍, 即ち実空間の視野領域と撮像素子の大きさを $1: 1$ としてい る. 弚の結果，レーザシート厚の増加につれ撮影された粒子の奥行き方向の位置の分布が広がり，弚の関数であ る粒子像の幅の分散が増加した . 一方, 干渉像幅の平均值はレーザシートと受光装置の距離に依存し, 送光光軸 と受光系の相対位置が変化しなければ一定である . 従って, 干渉像幅のばらつきは, レーザシート厚さの増加と ともに増大することが分かった . 本計測条件においては干渉像の幅の分散はレーザシート $5 \mathrm{~mm}$ の場合において 


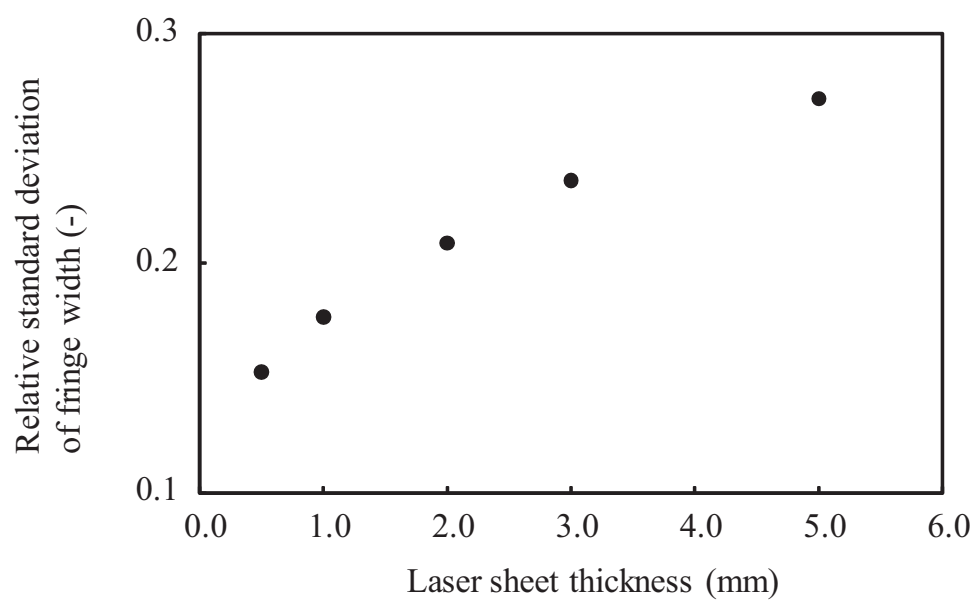

Fig. 4 Relative variation of the measured fringe width in terms of the laser sheet thickness.

$28 \%$ となることが確認された ．

\section{$2 \cdot 2$ 粒径算出式の精度検証}

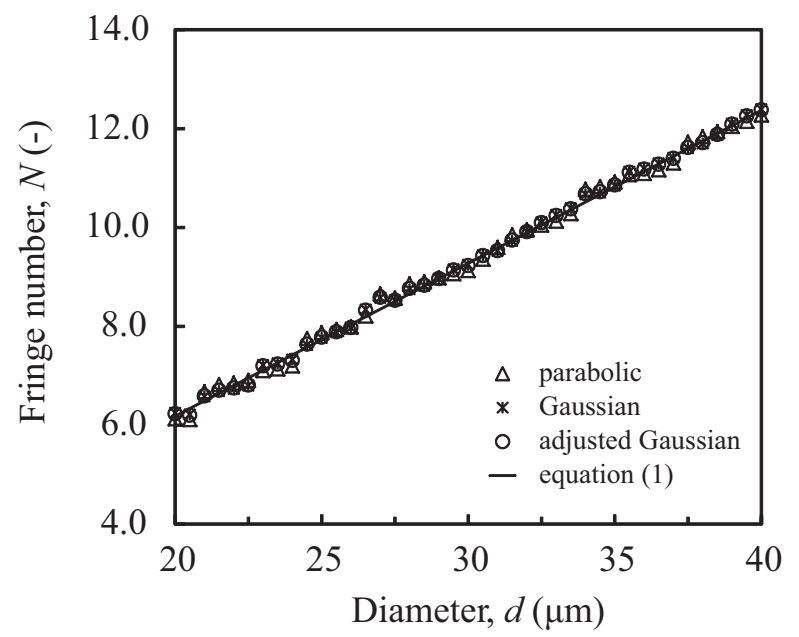

Fig. 5 Relation between droplet diameter and fringe number. The plots compare the dependency on the spectral fitting functions for the analytical Mie solution. Solid line is given by the sizing relation of equation (1).

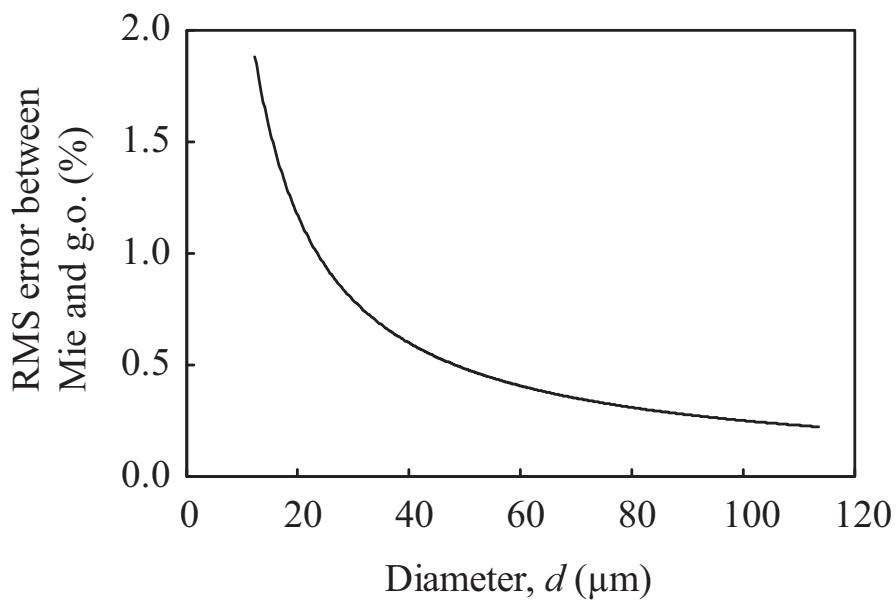

Fig. 6 Sizing error due to the geometric optical approximation in terms of the diameter.

粒径算出式 (1)の導出に用いられる仮定の妥当性及び幾何光学近似による誤差について, Mie 散乱理論を用いて 解析した . 図 5 は，Mie散乱理論に基づく計算により求めた粒径と干渉縞本数の関係であり，粒径範囲 $20 〜 40 \mu \mathrm{m}$ を表示した . 図中の各プロットは粒径を $0.5 \mu \mathrm{m}$ ずつ変化させ光散乱強度分布を計算し, 散乱パターンから所定の 集光角内の光強度分布を抽出し, 離散フーリエ変換によるパワースペクトル計算と, ピーク值と午の前後の計 3 点 の関数フィッティングによる周波数算定を, 粒径ごとに行ったものである.フィッティング関数を三種類 (parabolic: 放物線, Gaussian:ガウス関数, adjusted Gaussian : ガウス関数と 3 次関数による補正 ${ }^{(2)}$ ) 比較した . 屈折率は 1.36

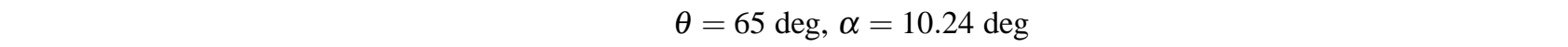
垂直である直線偏光 $i_{1}$ を用い, 波長は実験で用いたレーザ装置の発振波長と等しい $527 \mathrm{~nm}$ とした . また, 図中 の実線は, 式 (1)に示される幾何光学近似による粒径一干渉縞数関係である. 計算結果から, 放物線フィッティン グよりも Gauss 関数による算出のほうが全体的にばらつきが少なくなっているが, フィッティング関数に起因する 誤差と同程度の非線形性か確認された . 幾何光学近似により得られた粒径算出式と, Mie 散乱による厳密解とを比 
較すると，全体の傾向として平均値の差はごく僅かであり，粒径算出式を中心としてばらつきが発生する結果と なった .このことから，本計測手法により得られる算術平均径や確率密度分布への影響は結果的に小さいと考え られる .一方で, 粒径によらず一定量のばらつき誤差が生ずることが分かり，特に小径粒子においては粒子径に 対して相対的に誤差が大きくなる傾向があることが分かった .

以上の計算結果から，幾何光学近似に起因する誤差を粒径別に平均二乗誤差の相対値として求めた結果を図 6 に示す . Mie 散乱により計算された干渉縞本数によれば, 粒径算出式と厳密解とのばらつきはこの粒径範囲にお いて径にあまり依存せず，径が増加するにつれ粒径算出精度に与える $d-N$ 関係の非線形性の影響は相対的に軽 減される一方で , 小径の場合には誤差が上昇することが分かった . 弚の度合いは直径 $50 \mu \mathrm{m}$ 以上の液滴に対して

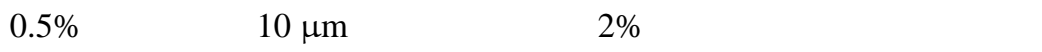

\section{$2 \cdot 3$ 屈折率変化の影響}

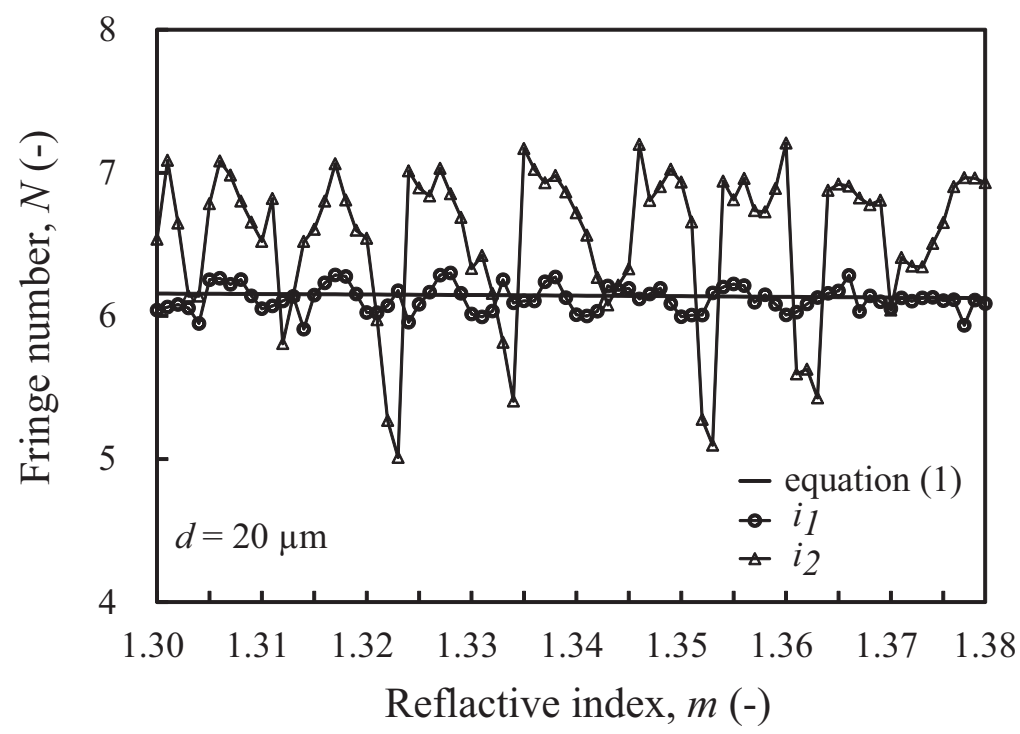

Fig. 7 Fringe count dependency on the refractive index in terms of the polarization of light. $i_{1}$ and $i_{2}$ represent the perpendicular and parallel polarization lights, respectively. Diameter and wavelength are $20 \mu \mathrm{m}$ and $527 \mathrm{~nm}$. Scattering angles is $65 \mathrm{deg}$, collecting angle is $10.24 \mathrm{deg}$.

液滴の蒸発・凝縮が起こる際には, 周囲環境との間に熱の授受が行われ, 結果として液滴の温度か変化し，ま たは液滴内部に温度分布が生ずることが考えられるため, 乥れにより屈折率が僅かに変化することから，粒径算 出精度に与える屈折率変化の影響を検討した . 著者らによる以前の研究においては, 粒径算出の際に等温系を仮 定する場合は屈折率を一定值とし，また温度が一定でない場合においても粒径算出式の特性からいずれも屈折率 を定数としてきた ${ }^{(15)}$. 图 7 は , 直径 $20 \mu \mathrm{m}$ の液滴に対して屈折率を 1.30 から 1.38 程度まで変化させた時の干渉 縞数の変化を, Mie 散乱理論および式 (1)により計算したものである.ここでは偏波面の直交する二つの直線偏 光 $i_{1}, i_{2}$ について比較した . $i_{1}$ は本実験で使用する散乱面に垂直な偏光， $i_{2}$ は散乱面と偏波面が平行な直線偏光を 表す. 散乱角を $65 \mathrm{deg}$, 集光角を $10.24 \mathrm{deg}$ とし, 角度方向の散乱光強度の計算分解能を $0.01 \mathrm{deg}$ とした . 前述 の Mie 散乱計算と同樣，干渉縞の波数をパワースペクトルの adjusted Gaussian フィッティング法により求めてい る.この比較結果から，通常の撮影に用いる直線偏光 $i_{1}$ が， 1.30 から 1.38 までの幅広い屈折率変化に対してほぼ 一樣な干渉縞本数を与えるのに対して，直交する直線偏光 $i_{2}$ では同一径であっても僅かな屈折率変化により最大 で $20 \%$ の渉縞数変化をもたらす可能性がある事が分かった . 一般的に温度の変化に起因する液体の屈折率変化 の程度は極めて小さく, 水の場合, 温度を $273.15 \mathrm{~K}$ から $373.15 \mathrm{~K}$ まで变化させた場合でも, 大気圧下での屈折率 変化は $0.2 \%$ 以であり, 結果として粒径算出に与える影響は極めて小さい. 即ち, 干渉縞数から粒径を算出する

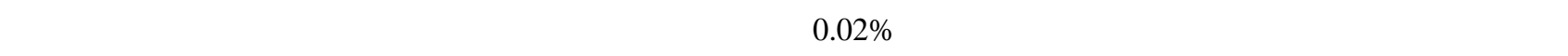

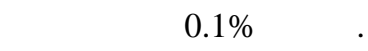




\section{3. 蒸発液滴の測定実験及び結果と考察}

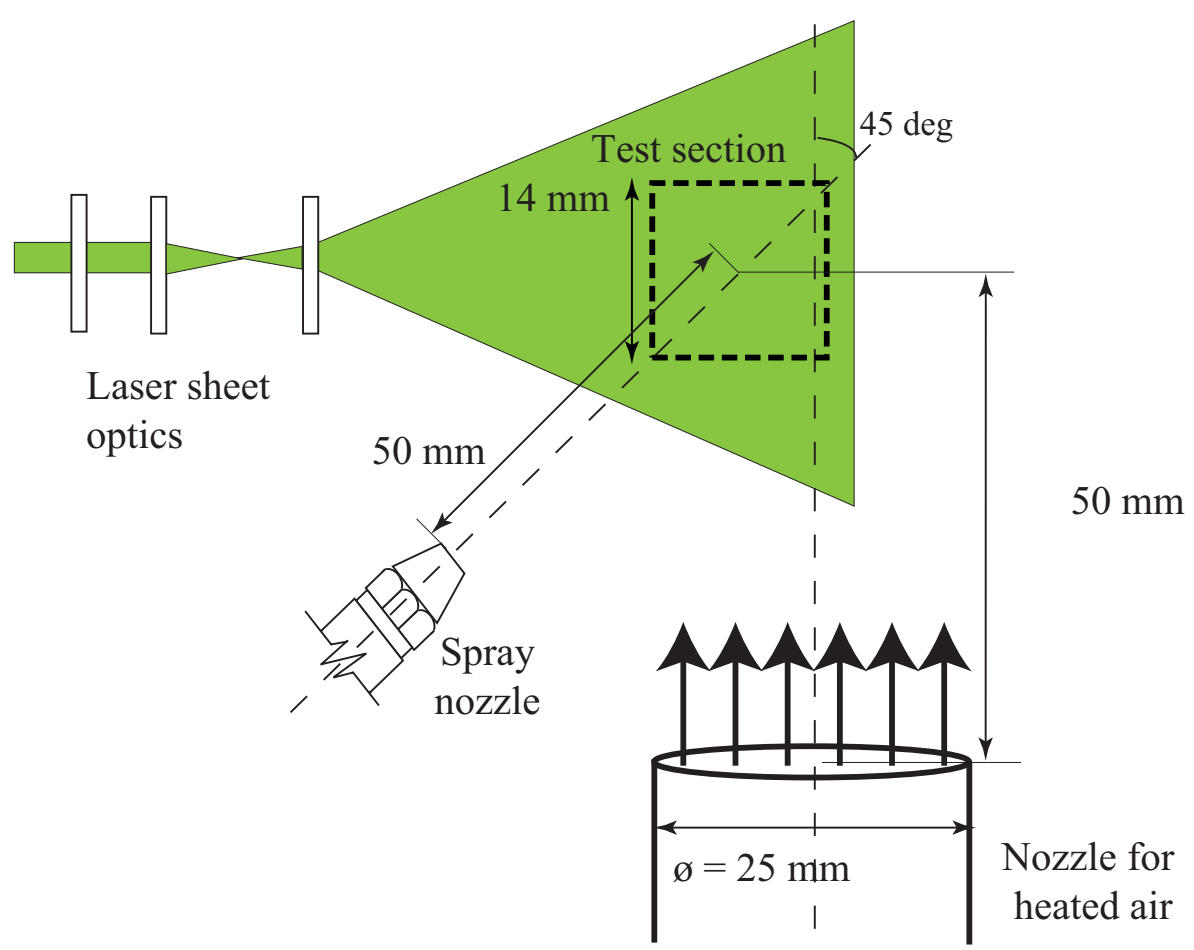

Fig. 8 The alignment of the spray nozzle, round nozzle for the heated air and laser sheet. The size and location of the test section are depicted.

図 8 に加熱空気による液滴の蒸発実験に用いた装置の概略図を示す. 実験装置は加熱した空気を鉛直上方に噴出 するための円形ノズルと，加熱空気中に液滴を導入するための液滴噴霧ノズルから成る . 液滴生成には DELAVAN 社製，噴角 $45 \mathrm{deg}$ のソリッドコーンタイプ噴霧ノズルを用い，作動流体としてエタノールを用いた . 噴霧ノズル は加熱空気用噴流の主軸に対して $45 \mathrm{deg}$ 傾け, 測定体積中心位置から $50 \mathrm{~mm}$ 離れた位置に設置した . 初期温度 $293 \mathrm{~K}$ のエタノールを $0.5 \mathrm{MPa}$ まで加圧し，噴霧ノズルを用いて加熱噴流中に噴霧させることにより加温・蒸発さ せ , 兴の挙動を計測した . 本実験で用いた噴霧ノズルにより得られる液滴の粒径および速度の平均值は, 噴霧ノ ズルからの距離 $40 \mathrm{~mm}$ の軸上において, 直径が $60 \mu \mathrm{m}$, 速度の絶対值が $7.3 \mathrm{~m} / \mathrm{s}$ である .

測定体積鉛直下方に設置した加熱空気供給用の円形ノズルは内径 $25 \mathrm{~mm}$ のステンレス製である. 円形ノズル の上流部に市販の工業用空気加熱電気ヒータおよびブロアを設置し, 円形ノズル出口における空気の平均温度が $570 \mathrm{~K}$ となるようヒータ出力を設定した . 流量と温度とが一定となる条件で鉛直上方に定常的に空気を噴出させ， 円形ノズル出口において速度および温度を計測し, 定常に達した後に測定を開始した . 円形ノズル出口の断面積 および加熱空気の流量の比から求まる平均流速を $u_{c}=20.0 \mathrm{~m} / \mathrm{s}$ とし，この流速と円形ノズルの内径 $\phi=25 \mathrm{~mm}$, および気体の動粘性係数 $v$ により定義される噴流のレイノルズ数を $\left(u_{c} \phi\right) / v=4 \times 10^{4}$ とした .

図 9 は，本実験条件におけるエタノール液滴の運動量緩和時間 $\tau_{v}$ および温度緩和時間 $\tau_{T}$ の粒径依存性を示す． 緩和時間の定義として，以下の式を用いた .

$$
\begin{aligned}
\tau_{v} & =\frac{\rho_{d} d^{2}}{18 \mu_{c}} \\
\tau_{T} & =\frac{\rho_{d} c_{d} d^{2}}{12 k_{c}}
\end{aligned}
$$

物性值は文献 ${ }^{(16)}$ より求め, 分散相であるエタノール液滴の密度, 比熱を光れぞれ $\rho_{d}=785 \mathrm{~kg} / \mathrm{m}^{3}, c_{d}=$ $2422 \mathrm{~J} / \mathrm{kg} \cdot \mathrm{K}$ とし, 連続相である加熱空気の粘性係数および熱伝導率を弚れ染れ $\mu_{c}=2.92 \times 10^{-5} \mathrm{~Pa} \cdot \mathrm{s}, k_{c}=$ $4.8 \times 10^{-2} \mathrm{~W} / \mathrm{m} \cdot \mathrm{K}$ とした . 図 9 より，速度および温度に関する典型的な緩和時間は， $d=50 \mu \mathrm{m}$ の液滴に対 して $3.7 \mathrm{~ms}$ および $8.3 \mathrm{~ms}, d=80 \mu \mathrm{m}$ の液滴に対して $9.6 \mathrm{~ms}$ および $21.2 \mathrm{~ms}$ である .これによれば，本実験で用 


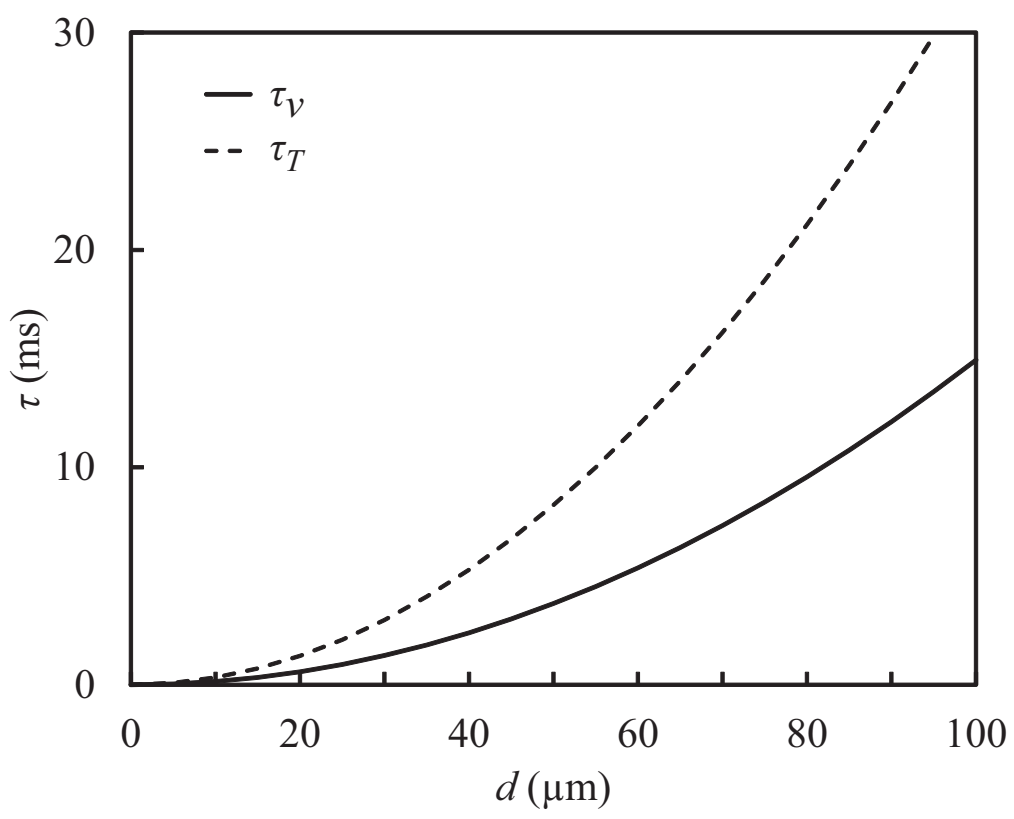

Fig. 9 Relaxation times of momentum and temperature of ethanol droplet in terms of a diameter. Solid and dashed lines represent the relaxation times of momentum and temperature respectively.

いた噴霧ノズルから生成される液滴の緩和時間は，計測のサンプリング周期より充分に長く，また，測定体積内 を通過するのに要する時間と同程度であることがわかる . 即ち , 検査体積内で速度および温度が周囲の加熱され た空気に追従する過程を観察できる条件が選択されていることが確認された .

計測結果の一例として , 測定領域内に検出された液滴のうち, 連続する数フレーム以上の画像にわたり干渉像が 検出され，かつ，干渉信号の $\mathrm{S} / \mathrm{N}$ 比が $10 \mathrm{~dB}$ 以上の液滴の軌跡を図 10 に示す. 矩形領域の実寸法は $14 \mathrm{~mm} \times 14 \mathrm{~mm}$ である . 図中の白丸は粒子の位置を表し，円の中心から描かれている矢印は瞬時の速度ベクトルを表す . また , 液 滴が測定体積内において初めて検出された時の初期液滴径を，図中に数値で示している. 液滴の位置, 径および 速度の算出は既報 ${ }^{(7)}$ の処理方法と同樣，まず得られた干渉画像から干渉縞の位置を検出し，輝度値の重心を粒子位 置とした . 輝度值の重心位置を中心として, 離散フーリエ変換およびパワースペクトルの関数フィッティングによ る周波数解析により干渉縞周波数を計算し, 粒径算出式(1)より液滴径を決定した . 次に , 一枚の画像から検出さ れた干渉縞像を第 1 探索空とし，次の時刻に撮影された画像内の同位置を中心に第 2 探索空を設定して光れ光れ の液滴に対して相互相関係数を計算し, 光のピーク位置から移動量を算出した .この際, 相互相関係数のピーク 值と光の周囲 4 点の值を用いてガウス関数によるフィッティングを行い, サブピクセル移動量を算出した . 得られ た移動量を画像撮影の時間間隔で除することにより，個々の液滴の移動速度とした . 粒子の速度分布より，液滴は 加熱空気の主流方向とほぼ平行に, 鉛直上方に運動することが確認された . また , 加熱噴流の中心軸は, 測定体 積内の $x=12.5 \mathrm{~mm}$ の位置に相当し, 中心軸から遠ざかるにつれ, 気相からの運動量の授受が低下し, 液滴速度 が低くなっていることがわかる．

図 11 は, 異なる位置における初期径のほほ等しい2 2 つ液滴 $d_{0}=80.7 \mu \mathrm{m}$ (液滴 $\mathrm{A}$ とする)および $d_{0}=77.8 \mu \mathrm{m}$ (液 滴 $\mathrm{B}$ とする) について, 兴の径の 2 乗の時間変化を示す . いずれの直径も初期液滴径 $d_{0}$ により無次元化している . これらの液滴は, 測定体積内の異なる位置において検出されたものであり，周囲流の条件が大きく異なると考え られる . 液滴 A は図 10 中の左側 $x=3.0 \mathrm{~mm}, y=4.3 \mathrm{~mm}$ を初期位置とする液滴であり，他方，液滴 $\mathrm{B}$ は同図中の 右側, 加熱噴流中心軸に近い $x=9.6 \mathrm{~mm}, y=4.5 \mathrm{~mm}$ を初期位置とする液滴である . これらの比較によれば, 後 者の加熱空気噴流の中心軸近傍において測定された液滴は, 光の速度の絶対值が大きく, 液滴径の減少速度が相 対的に大きいのに対し，前者は移動速度の絶対值が小さく，径の減少速度も遅いことが示されている．

蒸発速度の評価に関して，液滴を球形とすると，質量基準の物質移動流束 $N_{A}$ は，以下の式で表される . 


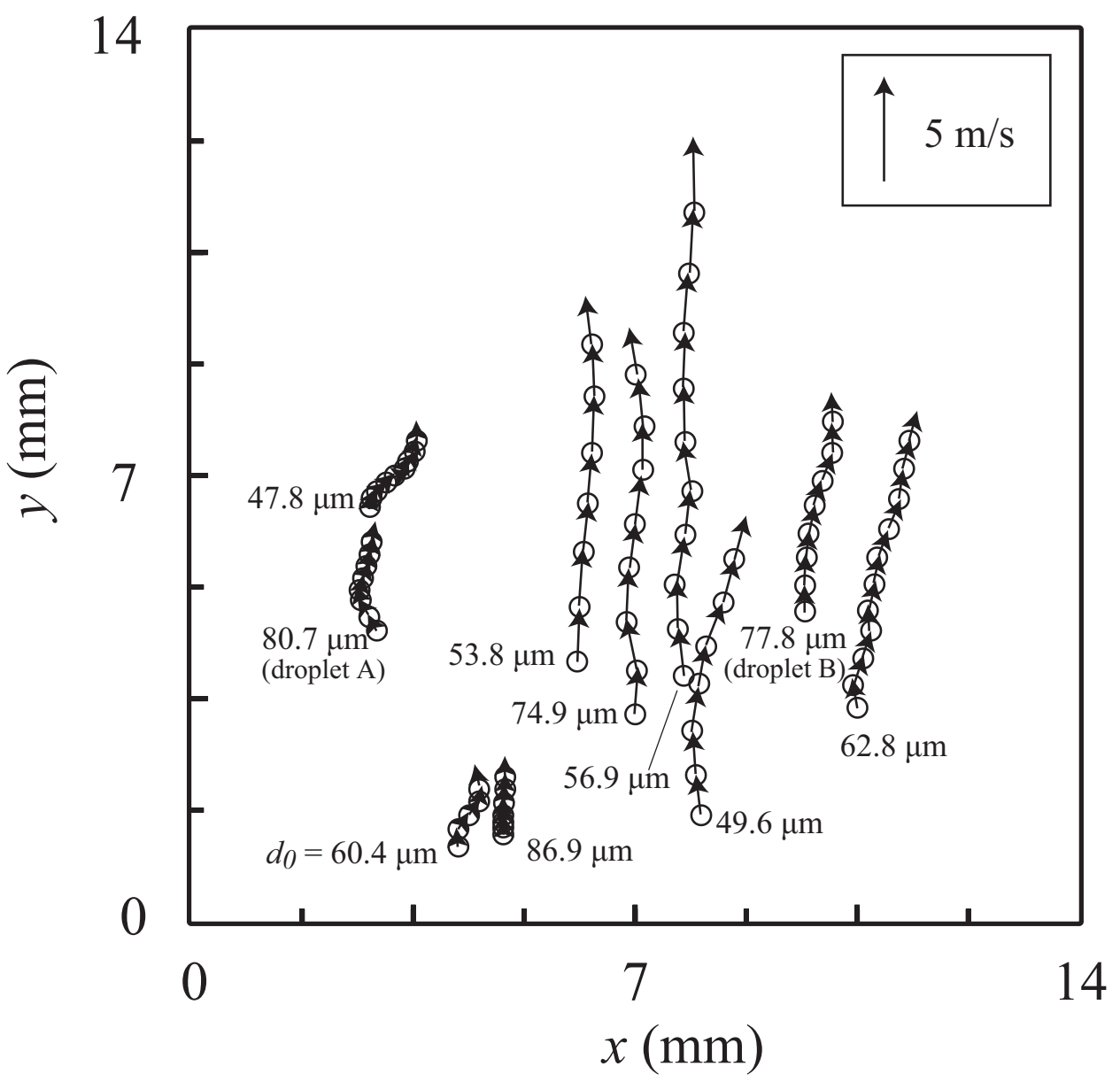

Fig. 10 Measured particle trajectories by particle tracking. Hollow circles and corresponding arrows represent the instantaneous droplet locations and the individual velocity vector respectively. Framerate of the image acquisition is $4000 \mathrm{~Hz}$, consequently the temporal resolution of the droplet sizing and velocimetry is $0.25 \mathrm{~ms}$. Initial droplet diameters are depicted in the vicinity of the initial droplet locations.

$$
\begin{aligned}
N_{A} & =\rho_{d} \frac{d V}{d t} / A=\rho_{d} \frac{d V}{d r} \frac{d r}{d t} / A \\
& =\rho_{d} \frac{d r}{d t}
\end{aligned}
$$

$A, V$ は光れ光れ液滴の表面積および体積を表す.$r$ は液滴の半径 $(=d / 2)$ であり， $\rho_{d}$ は本実験においてはエ夕 ノールの密度である。

図 12 は, 図 11 に示した 2 つの液滴径の時間変化をもとに，式(4) を用いて計算した物質移動流束を表す .こ れによると, 液滴 A の物質移動流束 $N_{A}$ は $0.18 \mathrm{~kg} / \mathrm{m}^{2} \cdot \mathrm{s}$ であり，測定時間内においてほぼ一定值であるのに対し て, 加熱噴流中心部の液滴 B の $N_{A}$ は初期において液滴 $\mathrm{A}$ に対して 1.6 倍の值であり，時間の経過とともに増大 し $0.52 \mathrm{~kg} / \mathrm{m}^{2} \cdot \mathrm{s}$ まで上昇した . また, 図 9 によれば, どちらの液滴も温度の緩和時間は $20 \mathrm{~ms}$ 程度であり, 液滴 の速度を考慮すると，噴霧された液滴が高温空気中に進入して測定体積に到達するまでに温度が充分に緩和して いないと考えられる、特に，液滴 B における物質移動流束の増加は，液滴温度か継続的に上昇中であるか，また は相対速度の増大等による Sh 数の増加を示唆している. 同樣の計算手順を用いて他の液滴についても光れ物 質移動流束を求めた結果，画像中の左半分の加熱噴流周辺部における $N_{A}$ の平均値は $0.20 \mathrm{~kg} / \mathrm{m}^{2} \cdot \mathrm{s}$ ，画像中の右半 分において $0.61 \mathrm{~kg} / \mathrm{m}^{2} \cdot \mathrm{s}$ となり，加熱噴霧中心部において高い物質移動流束となることか確認された .

ここで, 物質移動流束を界面における拡散流束の代表值で無次元化したシャーウッド数の定義は， 


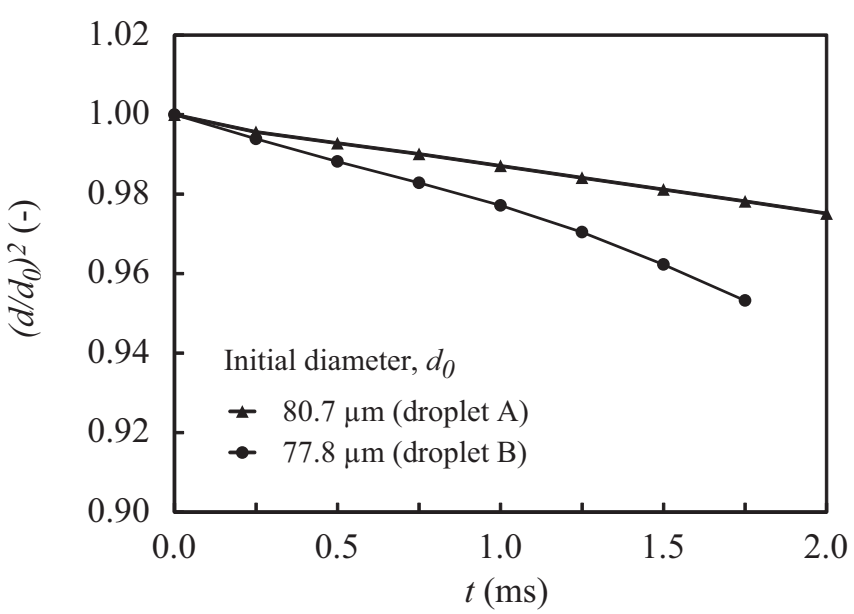

Fig. 11 Temporal size transition of droplets . Initial diameters are almost the same, however, the particle lo- Fig. 12 cation is different. The droplet $\mathrm{B}$ is located in the vicinity of the axis of a heated jet, and has relatively higher rate of the size reduction.

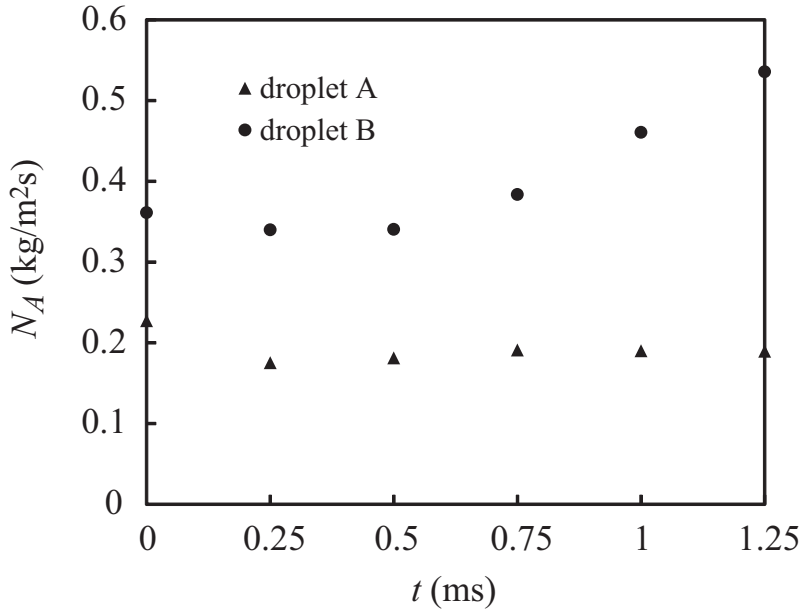

Comparison of mass transfer rate between two droplets located in the different environment.

$$
S h \equiv \frac{N_{A}}{\rho_{c} D\left(\omega_{s}-\omega_{\infty}\right) / 2 r}
$$

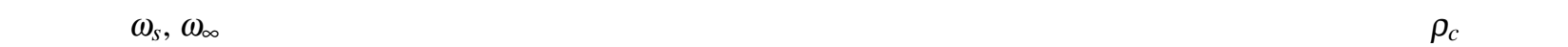
相の密度,$D$ は空気中におけるエタノールの拡散係数である.式(4)より， $N_{A}$ を消去して，

$$
2 r \frac{d r}{d t}=S h \frac{\rho_{c}}{\rho_{d}} D\left(\omega_{s}-\omega_{\infty}\right)
$$

が得られる .ごく短時間の間には, 液滴周囲の状態は変化せず一定であると仮定すると, 右辺を定数として積 分することにより

$$
d^{2}=(2 r)^{2}=d_{0}^{2}-K t \quad K=4 S h \frac{\rho_{c}}{\rho_{d}} D\left(\omega_{s}-\omega_{\infty}\right)
$$

となり，粒径の二乗が経過時間の一次関数となる $d^{2}$ 則 ${ }^{(17) ~(21)}$ が得られる．ここで， $K$ は蒸発速度定数である． また, $d=0$ とすると, 液滴の蒸発時間 $\tau_{d}=d_{0}^{2} / K$ が得られる.これは, 蒸発速度定数と一定としたときの, 液滴 か完全に蒸発するまでの時間を表す . 前述の液滴 A,B について計測データの得られた $1 \mathrm{~ms}$ 内の平均的な蒸発速度 定数を計算すると，光れ光れ $K=7.87 \times 10^{-8} \mathrm{~m}^{2} / \mathrm{s}, K=15.7 \times 10^{-8} \mathrm{~m}^{2} / \mathrm{s}$ となった .これらの結果から，初期径 がほぼ同一であるが, 周囲の流動状況の異なる位置に存在する液滴は, 粒径の時々刻々の変化から計算された物 質移動流束が大きく異なっており，产の蒸発速度定数は本実験の測定体積内において 2 倍程度異なることが分かっ た . 測定体積通過後も同一の速度で蒸発が進行すると仮定すると, 上記定数から液滴 A,B の蒸発時間は光れ光れ $82.6 \mathrm{~ms}, 38.6 \mathrm{~ms}$ と見積もることができる .

ここで, 液滴の蒸発に関して , Ranz と Marshall ら ${ }^{(22)(23)}$ によれば, 以下の関係が半実験式として得られている.

$$
\operatorname{Sh}\left(1-\omega_{s}\right)=2.0+0.6 S c^{1 / 3} R e_{p}^{1 / 2}
$$

$S c$ はシュミット数, $R e_{p}$ は粒子直径を代表長さ, 相対速度を代表速度とする粒子レイノルズ数であり， 


$$
R e_{p} \equiv \frac{\left|u_{d}-u_{c}\right| d}{v_{c}}
$$

と定義される．本実験条件においては，加熱空気の流量と，噴霧ノズルより噴霧されるエタノールの質量流量 比は約 150:1 であるため, 液滴蒸発によるエタノール濃度の増加は微小である . また , 実験結果より液滴数密度は 低く, 濃度に関する液滴間の相互干渉を無視することができる.従って, 液滴から離れた位置でのエタノールの質 量分率を $\omega_{\infty}=0$ として , 式(5)および式 (8) を用いて

$$
\begin{aligned}
\omega_{s} & =\frac{N_{A}}{S h\left(1-\omega_{s}\right) \rho D / d+N_{A}} \\
& =\frac{N_{A}}{\left(2.0+0.6 S c^{1 / 3} \operatorname{Re}_{p}^{1 / 2}\right) \rho D / d+N_{A}}
\end{aligned}
$$

が得られる.空気流の速度を一定とし, 計測された各液滴の直径および速度から粒子レイノルズ数を求め, ま た, 直径の時間変化から求まる $N_{A}$ を計算することにより, 液滴 $\mathrm{A}, \mathrm{B}$ の表面におけるエタノールの質量分率は光 れ光れ $\omega_{s}=0.22$ および 0.43 となる . 蒸発過程にある液滴表面においては, エタノールが飽和状態であると考えら れるため，理想気体の状態方程式および Dalton’s law より，エタノールの質量濃度は

$$
\omega_{e}=\frac{p_{e}}{p} \frac{M_{e} / M_{a}}{1-\left(1-\left(M_{e} / M_{a}\right)\right)\left(p_{e} / p\right)}
$$

と表される $p, M$ は光れぞれ圧力, 分子量であり，添え字の $e, a$ は光れ光れエタノール，空気を表す．これよ りエタノールの分圧は

$$
p_{e}=\frac{\omega_{e}}{\omega_{e}+\left(M_{e} / M_{a}\right)-\omega_{e}\left(M_{e} / M_{a}\right)}
$$

と表される . 全圧に対する成分分圧の比は温度の関数である飽和蒸気圧で与えられるため，常圧におけるエタ ノールの蒸気圧 ${ }^{(16)}$ より液滴表面の温度を推定すると，液滴 $\mathrm{A}, \mathrm{B}$ について光れ光れ $T_{s}=310 \mathrm{~K}$ および $325 \mathrm{~K}$ が得ら れる . 大気圧下におけるエタノールの沸点は約 $351 \mathrm{~K}$ であり，計測された液滴の速度および温度の緩和時間を考 慮すると，これらの液滴の温度は充分に緩和しておらず, 上昇過程にあると考えられる.とりわけ図 11 の粒径変 化に示されている通り，液滴 $\mathrm{B}$ は周囲空気流からの高い熱伝達による温度上昇の効果により，ほぼ一定の速度で

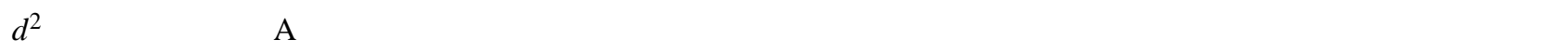
密な時間変化量から, 移動現象の解析に際し重要な量となる液滴表面の質量分率や, 分圧, さらには温度を算定 することができることが示された .

\section{4. 結言}

同期した高速度カメラおよび高繰返し周波数 Nd:YLFレーザを用いて, 液滴の蒸発過程をラグランジ的に計測 可能なダイナミック干渉画像法を開発した . 液滴の蒸発速度など時間微分量を正確に算出するため，まず粒径算 出式の導出過程を検討し, 幾何光学近似による計測誤差および温度变化に起因する屈折率変化の影響を Mie 散乱 理論を用いて比較, 検討した . エタノールを作動流体として市販の噴霧ノズルを用いて液滴を生成し，電気ヒー タにより加熱された軸対称噴流中に噴霧し, 開発した計測法により個々の液滴の粒径の時間変化を $0.25 \mathrm{~ms}$ の時間 分解能にて測定した . 得られた液滴径, 速度の時系列データより, 物質移動流束 , 蒸発速度定数, 液滴蒸発時間, 気液界面の質量分率など, 移動現象の解析およびモデリングの際に重要となる量を実験により算出することが本 手法により可能となった . 


\section{文献}

(1) Durst,F. and Zaré,M., "Laser Doppler Measurements in Two-Phase Flows", Proceedings of LDA Symposium, Copenhagen. (1975), pp.403-429.

(2) Kobashi,K., Hishida,K. and Maeda,M., "Measurement of Fuel Injector Spray Flow of I.C. Engine by FFT Based Phase Doppler Anemometer - An Approach to the Time Series Measurement of Size and Velocity”, Application of Laser Techniques to Fluid Mechanics ed R J Adrian et al. (Berlin:Springer) (1990), pp.268-287.

(3) Bachalo,W.D., Rudoff,R.C., Brenda,de la Rosa,A., "Mass flux measurements of a high number density spray system using the phase Doppler particle analyzer", AIAA (1988), 88-0236.

(4) Hesselbacher,K.H., Anders,K. and Frohn,A., "Experimental investigation of Gaussian beam effects on the accuracy of a droplet sizing method", Applied Optics, Vol. 30, No. 33 (1991), pp.4930-4935.

(5) Glover,A.R., Skippon,S.M. and Boyle,R.D., "Interferometric Laser Imaging for Droplet Sizing: A Method for Droplet-Size Measurement in Sparse Spray Systems”, Applied Optics, Vol.34, No.36 (1995), pp.8409-8421.

(6) Skippon,S.M. and Tagaki,Y., "ILIDS Measurements of the Evaporation of Fuel Droplets During the Intake and Compression Strokes in a Firing Lean Burn Engine”, SAE No.960830, 33 (1996), pp.183-198.

(7) Maeda,M., Kawaguchi,T. and Hishida,K., "Novel Interferometric Measurement of Size and Velocity Distributions of Spherical Particles in Fluid Flows", Measurement Science and Technology, Vol.11 (2000), pp.L13-L18.

（8）川口達也, 小林俊弘, 前田昌信, “レーザ干渉画像法による噴霧液滴径・速度の面的同時計測法の開発”, 日本機械学会論 文集 B 編, Vol.68, No.666 (2002), pp.431-438.

（9）川口達也, 赤坂幸広, 小林俊弘, 前田昌信, “レーザ干渉画像法による非定常噴霧流の粒径速度の空間分布計測”, 日本機械 学会論文集 B 編, Vol.68, No.666 (2002), pp.576-583.

(10) Godsave,G.A., "Burning of fuel droplets", Proceedings of the Combustion Institute, Vol.4 (1953), pp.818-830.

(11) Spalding,D.B., "The combustion of liquid fuels”, Proceedings of the Combustion Institute, Vol.4 (1953), pp.847-864.

(12) Kurosawa,R., Hishida,K. and Maeda, M., "Combined measurement of LIF and ILIDS for vapor concentration and droplets size and velocity in a spray", Proceedings 11th The International Symposia on Applications of Laser Techniques to Fluid Mechanics, Lisbon (2002), 25-5.

(13) Ungut,A., Gréhan,G. and Gouesbet,G., "Comparisons between Geometrical Optics and Lorenz-Mie Theory”, Applied Optics, Vol.20, No.17 (1981), pp.2911-2918.

(14) Girasole,T., Ren,K.F., Lebrun,D., Gouesbet,G. and Gréhan,G., "Particle Imaging Sizing: GLMT Simulations", Journal of Visualization, Vol.3, No.2 (2000), pp.195-202.

(15) Kawaguchi,T., Akasaka,Y. Hishida,K. and Maeda,M., "Planar Measurement of Local Characteristics of Impinging Spray on Heating Plate", Proceedings of the 6th ASME-JSME Thermal Engineering Joint Conference. (2003), TED-AJ03-370.

(16) 国立天文台編，理科年表，丸善 (2010)

(17) Faeth,G.M., "Current status of droplet and liquid combustion”, Progress in Energy and Combustion Science, Vol.3 (1977), pp.191224.

(18) Law,C.K., "Recent advances in droplet vaporization and combustion", Progress in Energy and Combustion Science, Vol.8 (1982), pp.171-201.

(19) Sirignano,W.A., "Fuel droplet vaporization and spray combustion theory", Progress in Energy and Combustion Science, Vol.9 (1983), pp.291-332.

(20) Abramzona,B. and Sirignanoa,W.A., "Droplet vaporization model for spray combustion calculations", International Journal of Heat and Mass Transfer, Vol.32, 9 (1989), pp.1605-1618.

(21) Sirignano,W.A., Fluid Dynamics and Transport of Droplets and Sprays, Cambridge University Press, Cambridge (1999). 
(22) Ranz, W.E. and Marshall, W.R., "Evaporation from Drops, Part I”, Chemical Engineering Progress, Vol.48, No.3 (1952), pp.141146.

(23) Ranz, W.E. and Marshall, W.R., "Evaporation from Drops, Part II”, Chemical Engineering Progress, Vol.48, No.4 (1952), pp.173179. 